\title{
PENGAMBILAN KEPUTUSAN MAHASISWA DALAM MEMILIH PERGURUAN TINGGI SWASTA di PEKANBARU
}

\author{
Putri Wulandini S1, Roni Saputra ${ }^{2}$ \\ Universitas Abdurrab Pekanbaru \\ 1putri.wulandini@univrab.ac.id, 2roni.saputra@univrab.ac.id
}

\begin{abstract}
Education has the very centraled and strategic role, esspecially, if it is accorded to the quality increasing effort of the human resources. Because only for the qualitified human resources will be created the truely human value and dignity increasing. University as one of the important part in the education zone which is responed in effort to enrich the nation life and the very strategic role to make the part in avoiding the the human resources quality problem. Amount of the many University if seen from the University perspective will cause the high competition in taking the pre-colligian. Answering the problem which is exposed above., the study aimed to determine the promotion activity contribution, price contribution, location contribution, facility and insfratucture contribution, human resources quality contribution through the colligian's decision maker in choosing the private University. The used research design in the research was explanatory and confirmation research which amied to explain the causal relationship between variable through the hipothesis test and operated by the descriptive analysis maintain and verificative through the suvey. The research outcome was found the promotion contribution ( $\mathrm{p}$ value 0.00 ), price contribution of $\mathrm{p}$ value $=0,0001$, location contribution $p$ value $=0,0001$, facility and infrastructure contribution $p$ value $=0,0001$, human resources quality contribution $\mathrm{p}$ value 0,0001 throught the decision maker on all relating statistically. Suggested for the private University management in Pekanbaru was more selective, critism to develop the University, for finding the students so that want to be able to study in the private University. (a) for the next research becomes the basic that when wanting the consument according to the target, besides promotion, location which must be noticed, completely facility, competitive price.
\end{abstract}

Keywords: decision, promotion, price, location,

Abstrak-Pendidikan mempunyai peranan yang sangat sentral dan strategis, terutama jika dikaitkan dengan upaya peningkatan mutu sumber daya manusia (SDM). Karena hanya dengan sumber daya manusia yang berkualitaslah akan tercipta peningkatan harkat dan martabat manusia yang sejati. Perguruan Tinggi sebagai salah satu bagian penting dalam dunia pendidikan yang ikut bertanggungjawab dalam upaya mencerdaskan kehidupan bangsa mempunyai tanggungjawab dan peran yang sangat strategis untuk mengambil bagian dalam mengatasi permasalahan kualitas sumber daya manusia. Jumlah perguruan tinggi yang banyak ini bila dilihat dari perspektif perguruan tinggi akan mengakibatkan terjadinya persaingan yang ketat dalam menggaet calon mahasiswa. Untuk menjawab masalah yang telah dipaparkan di atas studi ini bertujuan untuk mengetahui: Kontribusi kegiatan promosi ,Kontribusi Harga ,Kontribusi Lokasi ,Kontribusi Sarana dan prasarana, Kontribusi Mutu SDM terhadap pengambilan keputusan mahasiswa dalam memilih perguruan tinggi swasta. Desain penelitian yang digunakan dalam penelitian ini adalah penelitian explanatory atau confirmation research yang bertujuan untuk 
menjelaskan hubungan kausal antara variabel melalui pengujian hipotesis dan dilaksanakan dengan pendekatan analisis deskriptif dan verifikatif melalui survey. Hasil penelitian didapatkan Kontribusi promosi ( $p$ value 0.00 ), Kontribusi biaya $p$ value $=0.0001$ ,Kontribusi lokasi $\mathrm{p}$ value $=0.0001$, Kontribusi sarana prasarana $\mathrm{p}$ value $=0.0001$, Kontribusi mutu SDM p value $=0.0001$ terhadap pengambilan keputusan semua nya berhubungan secara statistik. Disarankan Bagi pengelola perguruan tinggi swasta dipeknabaru, diminta lebih seleksit, lebih kritis dalam membangun perguruan tinggi, guna menjaring siswa-siswa agar mau mampu menuntut keilmuan yang ada di PTS. (a) Bagi peneli selanjutnya menjadi dasar bahwa ketika menginginkan konsumen sesuai target, selain promosi, lokasi jg harus diperhatikan, sarana dilengkapi, biaya kompetitif

Kata Kunci: Keputusan, Perguruan Tinggi Swasta

\section{PENDAHULUAN}

Pendidikan mempunyai peranan yang sangat sentral dan strategis, terutama jika dikaitkan dengan upaya peningkatan mutu sumber daya manusia (SDM). Karena hanya dengan sumber daya manusia yang berkualitaslah akan tercipta peningkatan harkat dan martabat manusia yang sejati. Hal ini relevan dengan yang diamanatkan dalam Undang- Undang Sisdiknas yang baru pasal 1 ayat 1 tentang pendidikan yang menyatakan "Pendidikan adalah usaha sadar dan terencana untuk mewujudkan suasana belajar dan proses pembelajaran agar peserta didik secara aktif mengembangkan potensi dirinya untuk memiliki kekuatan spiritual keagamaan, pengenalan diri, kepribadian, kecerdasan, akhlak mulia, serta ketrampilan yang diperlukan dirinya masyarakat, bangsa, dan negara.

Perguruan Tinggi sebagai salah satu bagian penting dalam dunia pendidikan yang ikut bertanggungjawab dalam upaya mencerdaskan kehidupan bangsa mempunyai tanggungjawab dan peran yang sangat strategis untuk mengambil bagian dalam mengatasi permasalahan kualitas sumber daya manusia. Selain itu perubahan paradigma pengelolaan pendidikan tinggi telah bergeser dari pendekatan sentralistik ke arah pendekatan desentralisasi serta terikat pada satu tujuan sebagaimana dirumuskan dalam Visi 2010

Pendidikan Tinggi Indonesia, yaitu pada tahun 2015 telah dapat diwujudkan sistem pendidikan tinggi termasuk perguruan tinggi yang sehat sehingga mampu memberikan kontribusi pada daya saing bangsa dengan ciri berkualitas, memberi akses dan berkeadilan serta otonomi (HELTS 20032010).

Di Propinsi Riau sebagai salah satu pusat pendidikan di kawasan barat Indonesia jumlah perguruan tinggi berkembang cukup signifikan baik Perguruan Tinggi Negeri maupun Perguruan Tinggi Swasta. Pada tahun 2013 jumlah perguruan tinggi swasta yang yang terdiri dari Universtas $6 \mathrm{bh}$, Sekolah Tinggi 27 bh, Politeknik 3 bh dan Akademi 36 bh.

Perkembangan perguruan tinggi swasta yang cukup pesat ini diharapkan bisa memberi kontribusi maksimal dalam pembangunan dalam berbagai sektor tidak hanya di Riau tetapi paling tidak Indonesia Barat. Selain itu diharapkan pula ke depan PTS yang ada di Riau mampu berkiprah dan menunjukkan kualiltasnya di level nasional.

Jumlah perguruan tinggi yang banyak ini bila dilihat dari perspektif perguruan 
tinggi akan mengakibatkan terjadinya persaingan yang ketat dalam menggaet calon mahasiswa. Berbagai potensi dan keunggulan yang dimiliki perguruan tinggi akan dikerahkan semaksimal mungkin dan menjadi nilai jual yang positip, namun sebaliknya perguruan tinggi yang tidak mampu dan tidak memiliki daya saing akan merasakan dampak dari persaingan ini berupa kurangnya jumlah mahasiswa.

Mengantisipasi fakta-fakta tersebut maka proses pengambilan keputusan mahasiswa dalam memilih perguruan tinggi swasta tertentu sangat penting untuk diketahui oleh para pengelola perguruan tinggi swasta melalui kajian perilaku konsumen.

Schiffman dan Kanuk (2007) menyatakan bahwa proses pengambilan keputusan sebagai proses penting dipengaruhi oleh lingkungan eksternal yang terdiri dari bauran pemasaran (produk, promosi, harga, distribusi) dan lingkungan sosial budaya (keluarga, sumber informasi, sumber non komersial, kelas sosial, budaya dan sub budaya). Kemudian lingkungan internal (faktor psikologis) yang terdiri dari motivasi, kepribadian, pembelajaran, persepsi, dan sikap.

Tuntutan konsumen dan calon konsumen terhadap atribut dan kinerja jasa pendidikan yang mereka dapatkan memicu meningkatnya intensitas persaingan antar penyedia jasa pendidikan tinggi. Sekarang ini penyedia jasa pendidikan tinggi dituntut untuk bisa menerapkan strategi pemasaran yang tepat dengan berusaha menawarkan jasa pendidikan tinggi yang sesuai dengan yang diharapkan calon konsumen.

Di era globalisasi ini perguruan tinggi harus berbasis pada mutu atau kualitas yaitu dengan melakukan kegiatan jasa pendidikan yang harus mempunyai keunggulan dibandingkan dengan perguruan tinggi lain. Yang kedua adalah dengan pengembangan Penggalian sebanyak mungkin tentang keinginan calon konsumen terhadap jasa yang akan mereka terima sangat penting untuk dilakukan. Keinginan konsumen akan memberi dampak yang sangat signifikan pada strategi organisasi dan strategi pemasaran.

Berdasarkan latar belakang tersebut diatas maka peneliti mengambil permasalahan untuk diteliti berkaitan dengan pengaruh bauran pemasaran terhadap perilaku calon konsumen dalam pemilihan sebuah perguruan tinggi swasta.

Berdasarkan identifikasi masalah dalam latar belakang penelitian, maka dapat dirumuskan beberapa masalah pokok penelitian sebagai berikut: (1) Berapa besar kontribusi kegiatan promosi terhadap pengambilan keputusan mahasiswa dalam memilih perguruan tinggi swasta, (2) Berapa besar kontribusi Harga terhadap pengambilan keputusan mahasiswa dalam memilih perguruan tinggi swasta. (3) Berapa besar kontribusi Lokasi terhadap pengambilan keputusan mahasiswa dalam memilih perguruan tinggi swasta. (4) Berapa besar kontribusi Sarana dan prasarana terhadap pengambilan keputusan mahasiswa dalam memilih perguruan tinggi swasta. (5) Berapa besar kontribusi Mutu SDM terhadap pengambilan keputusan mahasiswa dalam memilih perguruan tinggi swasta

konsumen perguruan tinggi terhadap proses pengambilan keputusan mahasiswa dalam memilih perguruan tinggi swasta, maka secara umum pengelola Perguruan Tinggi Swasta telah memperoleh gambaran yang berguna agar dapat lebih 
memfokuskan prioritas kepada hal-hal yang menjadi keinginan dan tuntutan mahasiswa sebagai konsumen dalam bentuk atribut kepuasan yang tinggi.

1. Memberikan masukan kepada para pengelola perguruan tinggi swasta dalam rangka peningkatan manajemen pengelolaan dengan memperpendek jarak antara tawaran pergurun tinggi dan keinginan masyarakat pada umumnya dan mahasiswa pada khususnya.

2. Sebagai salah satu kontribusi pemikiran dalam pengembagan ilmu pengetahuan pemasaran jasa, khususnya dalam bidang riset perilaku konsumen jasa pendidikan tinggi.

3. Sebagai bahan referensi bagi pihak yang berminat untuk memahami dan meneliti perilaku konsumen, khususnya perilaku mahasiswa dalam memilih perguruan tinggi swasta.

\section{METODOLOGI PENELITIAN}

\section{HASIL DAN PEMBAHASAN}

Distribusi Frekuensi Pengambilan Keputusan Mahasiswa dalam Memilih Perguruan Tinggi Swasta di Pekanbaru

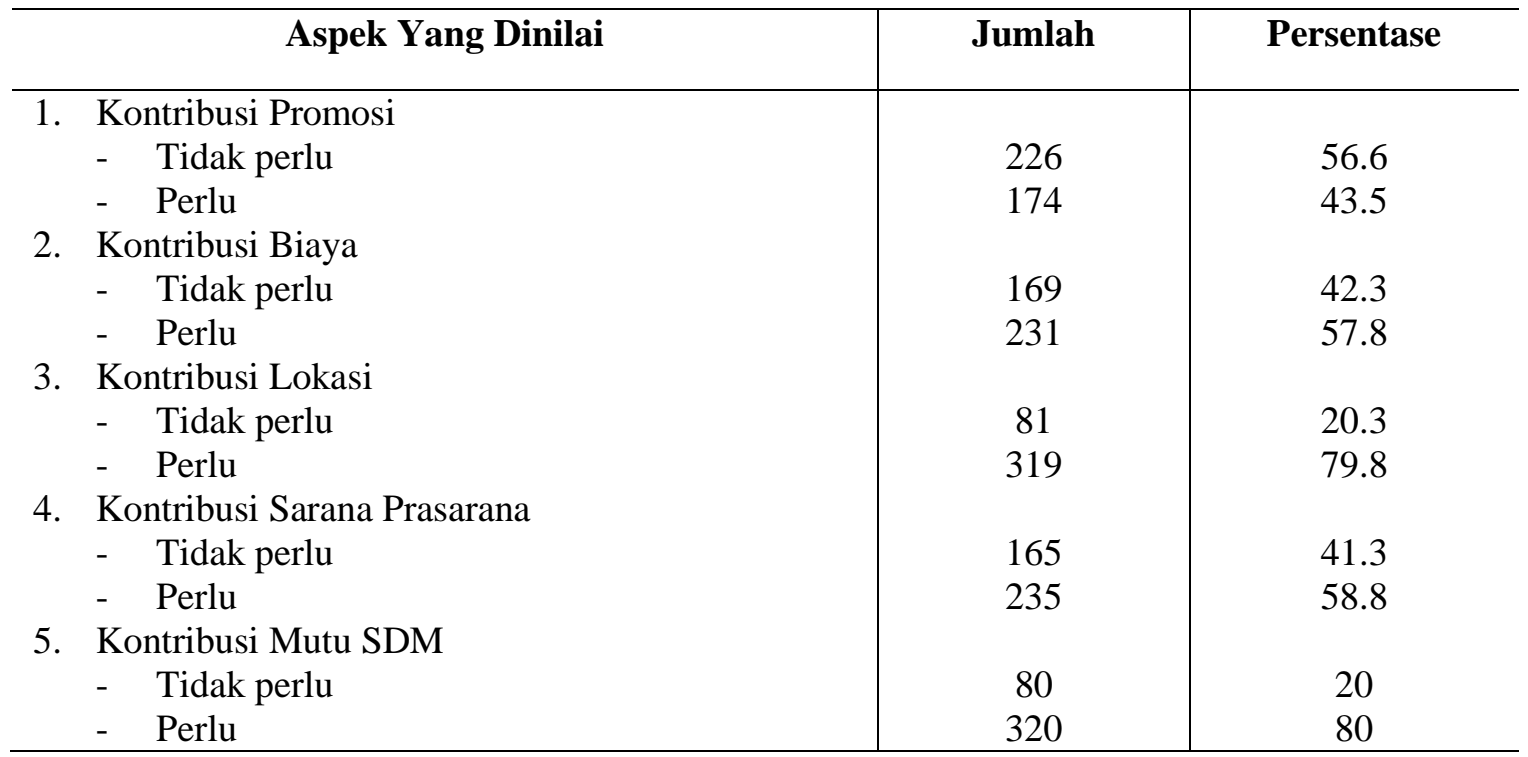

Desain penelitian yang digunakan dalam penelitian ini adalah penelitian explanatory atau confirmation research yang bertujuan untuk menjelaskan hubungan kausal antara variabel melalui pengujian hipotesis dan dilaksanakan dengan pendekatan analisis deskriptif dan verifikatif melalui survei (Rahayu, 2005).

Populasi penelitian ini ialah mahasiswa Universitas Swasta yang ada di Pekanbaru Riau. Jumlah keseluruhan pelajar universitas swata di Pekanbaru adalah sebanyak 22077 orang (Badan Statitistik Kota Pekanbaru, 2014).

Sampel ialah sebahagian atau wakil populasi yang diteliti mengusulkan rumus penentuan sampel minimum dengan pengambilan sampel mengikut nisbah tahap kesilapan 0.05 dan tahap keyakinan 95\%, sehingga jumlah sampel adalah: 400 Penetapan sampel untuk setiap universiti ditetapkan melalui perhitungan proporsional random sampling. 


\section{Keputusan \\ - Tidak memutuskan \\ - Memutuskan TOTAL}

Dari tabel 1terlihat bahwa dari 5 aspek kontribusi yang dinilai pada pengambilan keputusan mahasiswa dalam memilih perguruan tinggi swasta di pekanbaru adalah, factor kontribusi promosi didapatkan 56.6\% (226 responden) menyatakan tidak menjadi dasar pertimbangan dalam memilihi tempat kuliah. factor kontribusi biaya didapatkan $57.8 \%$ (231 responden) menyatakan biaya perlu menjadi dasar pertimbangan dalam memilihi tempat kuliah. factor kontribusi lokasi didapatkan $79.8 \%$ (319 responden)

Tabel 2 Analisis BivariaT

\begin{tabular}{|c|c|c|c|c|c|c|}
\hline \multirow[t]{3}{*}{ Independen } & \multicolumn{2}{|c|}{ Keputusan } & \multicolumn{2}{|c|}{ Total } & \multirow[t]{3}{*}{ OR } & \multirow[t]{3}{*}{ P value } \\
\hline & Tidak & Memutuskan & & & & \\
\hline & $\mathbf{n}$ & $\mathbf{n}$ & $\mathbf{n}$ & $\%$ & & \\
\hline $\begin{array}{l}\text { Kontribusi } \\
\text { Promosi } \\
\text { - Tidak Perlu } \\
\text { - Perlu } \\
\text { Total }\end{array}$ & $\begin{array}{c}109 \\
54 \\
167\end{array}$ & $\begin{array}{l}117 \\
120 \\
237\end{array}$ & $\begin{array}{l}226 \\
174\end{array}$ & $\begin{array}{l}100 \\
100 \\
100\end{array}$ & 12.040 & 0.001 \\
\hline $\begin{array}{l}\text { Kontribusi } \\
\text { Biaya } \\
\text { - Tidak Perlu } \\
\text { - Perlu } \\
\text { Total }\end{array}$ & $\begin{array}{c}100 \\
63 \\
163\end{array}$ & $\begin{array}{c}69 \\
168 \\
237\end{array}$ & $\begin{array}{l}169 \\
231 \\
400\end{array}$ & $\begin{array}{l}100 \\
100 \\
100\end{array}$ & 41.131 & 0.000 \\
\hline $\begin{array}{l}\text { Kontribusi } \\
\text { Lokasi } \\
\text { - Tidak Perlu } \\
\text { - Perlu } \\
\text { Total }\end{array}$ & $\begin{array}{c}51 \\
112\end{array}$ & $\begin{array}{c}30 \\
207\end{array}$ & $\begin{array}{c}81 \\
319\end{array}$ & $\begin{array}{l}100 \\
100\end{array}$ & 20.756 & 0.000 \\
\hline
\end{tabular}




\begin{tabular}{l|c|c|c|c|c|c}
\hline & 163 & 237 & 400 & 100 & & \\
\hline $\begin{array}{l}\text { Kontribusi } \\
\text { Sapra }\end{array}$ & & & & & & \\
$\begin{array}{l}\text { - Tidak Perlu } \\
\text { - Perlu } \\
\text { Total }\end{array}$ & 94 & 71 & 165 & 100 & 30.602 & 0.000 \\
& 69 & 166 & 235 & 100 & & \\
& 163 & 237 & 400 & 100 & & \\
\hline $\begin{array}{l}\text { Kontribusi } \\
\text { Mutu SDM }\end{array}$ & & & & & & \\
- Tidak Perlu & 50 & 30 & 80 & 100 & 19.593 & \\
- Perlu & 113 & 207 & 320 & 100 & & \\
Total & 163 & 237 & 400 & 100 & & \\
& & & & & \\
\end{tabular}

Hasil analisis siginifikansi atau uji statistik antara kontribusi promosi dengan pengambilan keputusan mahasiswa dalam memilih perguruan tinggi swasta di pekanbaru didapatkan $\mathrm{p}$ value $=0.001$ maka hal ini bermakna ada hubungan antara kontribusi promosi dengan pengambilan keputusan mahasiswa dalam memilih perguruan tinggi swasta, $\mathrm{OR}=$ 12.040 artinya kontribusi promosi berpeluang 12 kali dalam pengambilan keputusan mahasiswa saat memilih perguruan tinggi swasta dipekanbaru.

Hasil analisis siginifikansi atau uji statistik antara kontribusi biaya dengan pengambilan keputusan mahasiswa dalam memilih perguruan tinggi swasta di pekanbaru didapatkan $p$ value $=0.0001$ maka hal ini bermakna ada hubungan antara kontribusi biaya dengan pengambilan keputusan mahasiswa dalam memilih perguruan tinggi swasta, $\mathrm{OR}=$ 41.131 artinya kontribusi biaya berpeluang 41 kali dalam pengambilan keputusan mahasiswa saat memilih perguruan tinggi swasta dipekanbaru.

Hasil analisis siginifikansi atau uji statistik antara kontribusi lokasi dengan pengambilan keputusan mahasiswa dalam memilih perguruan tinggi swasta di pekanbaru didapatkan $\mathrm{p}$ value $=0.0001$ maka hal ini bermakna ada hubungan antara kontribusi lokasi dengan pengambilan keputusan mahasiswa dalam memilih perguruan tinggi swasta, $\mathrm{OR}=$ 20.756 artinya kontribusi lokasi berpeluang 20 kali dalam pengambilan keputusan mahasiswa saat memilih perguruan tinggi swasta dipekanbaru.

Hasil analisis siginifikansi atau uji statistik antara kontribusi sarana prasarana dengan pengambilan keputusan mahasiswa dalam memilih perguruan tinggi swasta di pekanbaru didapatkan $p$ value $=0.0001$ maka hal ini bermakna ada hubungan antara kontribusi sarana prasarana dengan pengambilan keputusan mahasiswa dalam memilih perguruan tinggi swasta, $\mathrm{OR}=30.602$ artinya kontribusi sarana prasarana berpeluang 30 kali dalam pengambilan keputusan mahasiswa saat memilih perguruan tinggi swasta dipekanbaru.

Hasil analisis siginifikansi atau uji statistik antara kontribusi Mutu SDM dengan pengambilan keputusan 
mahasiswa dalam memilih perguruan tinggi swasta di pekanbaru didapatkan $p$ value $=0.0001$ maka hal ini bermakna ada hubungan antara kontribusi Mjutu SDM dengan pengambilan keputusan mahasiswa dalam memilih perguruan tinggi swasta, $\mathrm{OR}=19.593$ artinya kontribusi mutu SDM berpeluang 19 kali dalam pengambilan keputusan mahasiswa saat memilih perguruan tinggi swasta dipekanbaru.

\section{Implikasi Hasil Penelitian :}

\section{A. Implikasi Kegiatan promosi} berpengaruh terhadap pengambilan keputusan mahasiswa dalam memilih perguruan tinggi swasta.

Kegiatan promosi berpengaruh terhadap pengambilan keputusan mahasiswa dalam memilih perguruan tinggi swasta. Dapat ditegas bahwa promosi melalui produk adalah yang paling besar pengaruhnya. Hal ini menunjukkan peran penting komunikasi dalam menunjang proses keputusan pembelian, seperti yang disampaikan oleh Henry Assael dalam Jamaluddin Sawaji, Djabir Hamzah, dan Idrus Taba ( 2014 ) sebagai berikut: "Since they provide information that influences consumer's puchase, communications are central to consumer's decision making". Untuk itu tidaklah cukup bagi perusahaan hanya sekedar mengembangkan produk dengan baik, menawarkan dengan harga menarik, dan membuatnya mudah diperoleh pelanggan sasarannya. Namun perusahan harus juga berkomunikasi dengan para pelanggan yang ada sekarang, pelanggan potensial (Jamaluddin Sawaji, Djabir Hamzah, dan Idrus Taba, 2014).

Perguruan Tinggi harus dapat selalu menjaga komunikasi dengan konsumen atau calon mahasiswanya. Jangan sampai putus informasi dari universitas kesekolah tempat para cakon berkumpul. Sudah seharusnya Perguruan Tinggi membuat terobosan dalam promosi dengan cara meningkatkan kuatitas jalinan komunikasi, misalnya dengan berkomunikasi satu kali tiap semester.

\section{B. Implikasi Biaya berpengaruh} terhadap pengambilan keputusan mahasiswa dalam memilih perguruan tinggi swasta.

Tinggi rendahnya harga atau biaya yang dibayarkan hasil penilaian yang dilakukan sangat tergantung kepada kemampuan ekonomi, kondisi dan pola penilaiannya secara subyektif dengan mengaitkan misalnya dengan kemungkinan nilai atau kualitas yang akan diterima, keterjangkauan biaya pendidikan, kewajaran biaya pendidikan dan lain sebagainya. Schiffman dan Kanuk (2007) menjelaskan bahwa bagaimana konsumen memandang harga tertentu- tinggi, rendah, wajar, mempunyai pengaruh yang kuat terhadap maksud membeli dan kepuasan membeli. Ini menunjukkan bahwa seorang konsumen menilai kewajaran sebuah harga produk atau jasa sangat tergantung dari cara menilainya. Demikian pula yang dikemukakan oleh Mowen dalam Ndaru Kusuma Dewi (2009) bahwa konsumen cenderung menggunakan harga sebegai indikator kualitas.

Jadi besarnya biaya yang dibayarkan terhadap universitas memang menjadi penentu bagi calon mahasiswa untuk menentukan pilihan, akan tetapi harga atau biaya bukan faktordominan.

\section{Implikasi Lokasi berpengaruh terhadap pengambilan keputusan mahasiswa dalam memilih perguruan tinggi swasta}

Lokasi juga dianggap memiliki relevansi yang signifikan pada seseorang dalam hal mengevaluasi, memberikan aspirasi, atau dalam berperilaku (Solomon, 1999). Besarnya pengaruh 
lokasi terhadap keputusan pembelian dibuktikan melalui penelitian yang dilakukan oleh Bearden dan Etzel dalam (Peter dan Olson, 2000).

Namun dalam penelitian ini kecil sekali pengaruh lokasi terhadap keputusan memilih perguruan tinggi oleh mahasiswa.

\section{Implikasi Sarana dan prasarana} berpengaruh terhadap pengambilan keputusan mahasiswa dalam memilih perguruan tinggi swasta

Secara teori Ketersediaan sarana dan prasana pendukung sama halnya dengan kemasan sutu produk, semakin menarik kemasan suatu pruduk semakin punya nilai jual produk tersebut (Schiffman dan Kanuk, 2007). Kondisi fisik sebuah universitas menjadi ukuran bagi calon mahasiswa dalam mengambil keputusan apakah akan kuliah di suatu universitas atau tidak. Semakin baik kondisi fisik ( sarana dan prasarana) semakin berpengaruh terhadap pengambilan keputusan memilih tempaty kuliah. Sarana dan Prasana adalah lingkungan fisik dari perguruan tinggi yang mampu mempengaruhi kualitas pelayanan jasa meliputi : (1) gedung yaitu kondisi bangunan dan suasana tempat perkuliahan dilaksanakan. (2) perpustakaan yaitu kondisi perpustakaan baik kelengkapan sarana maupun prasarana yang dimiliki serta tenaga-tenaga yang melayani, ketenangan dan kenyamanannya (3) fasilitas olah raga yaitu kondisi fasilitas olahraga yang lengkap dan nyaman (4)fasilitas laboratorium yaitu kondisi laboratorium yang lengkap dan dapat dioptimalkan penggunaannya (5) fasilitas komputer yaitu kondisi komputer yang modern, lengkap dan penggunaannya optimal (6) fasilitas pendukung yaitu ketersediaan fasilitas pendukung yang memadai seperti kantin, tempat parkir yang aman, toilet yang bersih dan fasilitas pendukung perkuliahan yang canggih dan modern. (Schiffman dan Kanuk, 2007).

\section{E. Implikasi Mutu SDM berpengaruh terhadap pengambilan keputusan mahasiswa dalam memilih perguruan tinggi swasta.}

Sumber Daya Manusia (SDM) adalah personal dalam perguruan tinggi yang langsung maupun tidak langsung turut serta dalam proses-proses kegiatan akademik (Schiffman dan Kanuk, 2007). Mutu SDM perlu juga dikomunikasikan kepada calon mahasiswa karena mutu SDM juga berpengaruh terhadap pengambilan keputusan mahasiswa menetapkan perguruan tinggi yang akan dipilihnya sebagai tempat kuliah. Mutu SDM adalah personal dalam perguruan tinggi yang langsung maupun tidak langsung turut serta dalam prosesproses kegiatan akademik yang meliputi : (a) tenaga pengajar/ dosen yaitu kondisi tenaga pengajar baik secara kuantitas maupun kualitas bila dilihat dari latar belakang pendidikan $(\mathrm{S} 1, \mathrm{~S} 2, \mathrm{~S} 3)$ lulusan dalam atau luar negeri (b) tenaga administrasi yaitu kondisi tenaga administrasi baik secara kuantitas maupun kualitas dalam memberikan pelayanan kepada mahasiswa (c) pimpinan PTS yaitu yang mempunyai reputasi baik reputasi akademik maupun di masyarakat (Schiffman dan Kanuk, 2007).

\section{KESIMPULAN DAN SARAN}

Dari hasil penelitian yang telah dilakukan peneliti terhadap pengambilan keputusan mahasiswa dalam memilih perguruan tinggi swasta di pekanbaru adalah sebagai berikut :

a. Kontribusi promosi terhadap pengambilan keputusan $: p$ value $=$ 
0.001 bermakna ada hubungan antara kontribusi promosi dengan pengambilan keputusan mahasiswa dalam memilih perguruan tinggi swasta, $\mathrm{OR}=12.040$ artinya kontribusi promosi berpeluang 12 kali dalam pengambilan keputusan mahasiswa saat memilih perguruan tinggi swasta dipekanbaru.

b. Kontribusi biaya terhadap pengambilan keputusan : $\mathrm{p}$ value $=$ 0.0001 maka hal ini bermakna ada hubungan antara kontribusi biaya dengan pengambilan keputusan mahasiswa dalam memilih perguruan tinggi swasta, $\mathrm{OR}=41.131$ artinya kontribusi biaya berpeluang 41 kali dalam pengambilan keputusan mahasiswa saat memilih perguruan tinggi swasta dipekanbaru.

c. Kontribusi lokasi terhadap pengambilan keputusan : $\mathrm{p}$ value $=$ 0.0001 maka hal ini bermakna ada hubungan antara kontribusi lokasi dengan pengambilan keputusan mahasiswa dalam memilih perguruan tinggi swasta, $\mathrm{OR}=20.756$ artinya kontribusi lokasi berpeluang $20 \mathrm{kali}$ dalam pengambilan keputusan mahasiswa saat memilih perguruan tinggi swasta dipekanbaru.

d. Kontribusi sarana prasarana terhadap pengambilan keputusan $\mathrm{p}$ value $=$ 0.0001 maka hal ini bermakna ada hubungan antara kontribusi sarana prasarana dengan pengambilan keputusan mahasiswa dalam memilih perguruan tinggi swasta, $\mathrm{OR}=30.602$ artinya kontribusi sarana prasarana berpeluang 30 kali dalam pengambilan keputusan mahasiswa saat memilih perguruan tinggi swasta dipekanbaru.

e. Kontribusi mutu SDM terhadap pengambilan keputusan $\mathrm{p}$ value $=$ 0.0001 maka hal ini bermakna ada hubungan antara kontribusi Mjutu SDM dengan pengambilan keputusan mahasiswa dalam memilih perguruan tinggi swasta, $\mathrm{OR}=19.593$ artinya kontribusi mutu SDM berpeluang 19 kali dalam pengambilan keputusan mahasiswa saat memilih perguruan tinggi swasta dipekanbaru.

Disarankan Bagi pengelola perguruan tinggi swasta dipeknabaru, diminta lebih seleksit, lebih kritis dalam membangun perguruan tinggi, guna menjaring siswasiswa agar mau mampu menuntut keilmuan yang ada di PTS. (a) Bagi peneli selanjutnya menjadi dasar bahwa ketika menginginkan konsumen sesuai target, selain promosi, lokasi jg harus diperhatikan, sarana dilengkapi, biaya kompetitif serta mutu SDM pelaksananya.

\section{DAFTAR PUSTAKA}

[1] Agni Alam Wirya ,Indah Piliyanti (2009),Penggunaan Analisis Faktor untuk menentukan

[2] Kriteria Pemilihan Program Studi Ekonomi Islam,EKBISI, Vol 4 , no. 1, hal 85-97

[3] Al-FattalAnas (2010), Understanding Student Choice of University and Marketing Strategies inSyrian Private Higher Education,Doctor of Philosophy ,University of Leeds

[4] Fernandez Jacqueline Liza (2010),An explanatory study of factors influEencing the decision of students to study at universiti sains Malaysia,Kajian Malaysia, Vol. 28, No. 2, 2010

[5] Fandi Tjiptono, Gregorius Chandra dan Dedi Adriana, 2008, Pemasaran Strategik, Penerbit Andy, Jakarta.

[6] Fandi Tjiptono, Gregorius Chandra, 2011, Service, Quality dan Satisfaction, Penerbit Andy, Jakarta. 
[7] Ghozali Imam 2007, Aplikasi Analisis Multivariate dengan program SPSS ,Badan Penerbit Undip Indah Piliyanti Program Studi Ekonomi Islam : Perspektif Mahasiswa (sebuah Kajian Pemasaran Pendidikan,The 9th Annual Conference on Islamic Studies (ACIS)

[8] Umar, Husain, 2005. Riset Sumber Daya Manusia dan Organisasi. Jakarta: Gramedia Pustaka.

[9] Cetakan Ketujuh. Kotler, Philip and Amstrong, Gary, 2012, Principles Of Marketing,

[9] Fourteen Edition, Pearson Education Limited, England Kusumawati Andriani (2010)

[10] Privatization and marketization of Indonesian public universities : a systematic review of student choice criteria literature Research Online Sydney Business School - Papers

[11] Kotler,Philip dan Amstrong,Gary, 2009, Dasar-dasar Pemasaran,Penerbit PT Indeks Kelompok Gramedia, Jakarta

[12] Kotler, Philip dan Keller,Kevin, 2009, Manajemen Pemasaran, Penerbit Prenhalindo, Jakarta.

[13] Moses L. Singgih Rahmayanti ,Faktor faktor yang mempengaruhi kualitas pendidian kpada Perguruan Tinggi, Prosiding Seminar Nasional Teknoin 2008 Bidang Teknik Industri Md,

[14] Samsinar, Sidin Siti Rahayu Hussin, Tan Ho Soon (2003), An Exploratory Study of Factors Influencing the College Choice Decision of Undergraduate Students in Malaysia, Asia Pacific Management Review (2003) 8(3),259-280
[15] Mashur Razak,2008, Analisis proses pengambilan keputusan mahasiswa dalam memilih program studi pada PTS di Sulawesi Selatan,social and culture, reference group, marketing communication, Vol 5 No. 2: 89 - 102

[16] RaposoMário and Alves Helena (2007), A model of university choice: an exploratory approach,MPRA Paper no.5523, Management

and Economic Department NECE Research Unit Supranto, J, 2007, Perilaku Konsumen dan Strategi Pemasaran : Untuk memenangkan persaingan bisnis, Mitra Wacana Media, Jakarta

[17] Simamora, Bilson, 2002, Panduan Riset Perilaku Konsumen, PT Gramedia Pustaka Utama : Jakarta

[18] Siti Falindah Padlee, Abdul Razak Kamarudin, Rohaizat Baharun (2010) International Studens' Choice Behavior for Higher Education at Malaysian Private Universities, International Journal of Marketing Studies Vol. 2, No. 2;

[19] Simarmata Jonner, 2002 "Korelasi Motivasi Kerja dengan Kinerja",Jurnal Akademika, Volume 6 No 1 Umar, Husain, 2005. Riset Sumber Daya Manusia dan Organisasi. Jakarta: Gramedia Pustaka. Cetakan Ketujuh. Undang-Undang Sistem pendidikan nasional Nomor 20 Tahun 2003

[20] Wagner, K. \& Fard, P. Y. 2009, "Factors Influencing Malaysian Students' Intention to Study at a Higher Educational Institution." Chinese American Scholars Association, New York, New York, USA, Retrieved 11 July, 2009, from http://www.gcasa.com/PDF/malaysia/Wa gner-Fard.pdf 


\section{ISSH Jurnal SAINS SOSIAL \& HUMANIORA}

[21] Widyastuti, Suryaningsum dan Akuntansi, Simposium Nasional Juliana. 2004. Pengaruh Motivasi Akuntansi VII terhadap Minat Mahasiswa Akuntansi Untuk Mengikuti Pendidikan Profesi 